\title{
PENENTUAN MENU MAKANAN DALAM PEMENUHAN KEBUTUHAN KALORI BURUH PABRIK DENGAN ANALISIS DETAK JANTUNG
}

\author{
${ }^{1}$ Muhammad Hermansyah, ${ }^{2}$ M. Imron Mas'ud \\ 1,2Program Studi Teknik Industri Universitas Yudharta, Jl. Yudharta Sengonagung Purwosari Pasuruan \\ e-mail: hermansyah@ppp.rocketmail.com
}

\begin{abstract}
Abstrak
Sarana pendukung dan fasilitas yang diberikan perusahaan ternyata belum cukup menjamin karyawan sehat dan selamat dalam bekerja. Hal ini terlihat dari banyaknya karyawan terkena resiko gangguan kesehatan akibat ketidakseimbangan antara kebutuhan konsumsi tubuh dan energi yang menyebabkan penurunan produktivitas kerja. Jumlah kalori merupakan pendukung energi bagi karyawan yang dapat diukur melalui detak jantung buruh angkut pada saat beraktivitas, pengkonversian detak jantung ke dalam kebutuhan kalori, penentuan kandungan kalori pada makanan buruh angkut, dan penyusunan menu usulan dengan kandungan kalori sesuai kebutuhan. Tujuan dari penelitian adalah menghitung jumlah kalori yang dibutuhkan karyawan buruh angkut untuk mengatur pola asupan makanan yang tepat agar keperluan kalori dapat dipenuhi. Pengamatan secara langsung dilakukan terhadap objek pada saat melakukan sejumlah kegiatan dalam perusahaan maupun di lapangan. Hasil penelitian menunjukkan pekerjaan yang dilakukan buruh angkut adalah 1,5 jam pekerjaan berat, 5 jam pekerjaan sedang dan 1,5 jam istirahat dengan kebutuhan kalori rata-rata 1253.601 kal/8jam kerja. Tubuh akan mengalami kekurangan kalori pada saat mereka bekerja kurang lebih sekitar 6,5\% dari makanan yang telah mereka makan setiap harinya. Untuk itu dilakukan perbaikan menu makanan dengan rata-rata sebesar 1284,013 kal/8jam. Hasil perbaikan mampu meningkatkan produktivitas kerja karyawan yaitu dari 73,99\% menjadi $74,81 \%$.
\end{abstract}

Kata kunci : Detak jantung; kalori; produktivitas kerja

\section{PENDAHULUAN}

Persaingan dunia usaha yang ketat menyebabkan setiap pelaku usaha melakukan langkahlangkah yang dapat membawa usahanya menjadi pemenang di dunia industri, salah satunya dengan memberikan perhatian penuh terhadap produk maupun hasil produksi yang menjadi keluarannya (Suma'mur, 1987). Hal ini tentu tidak terlepas dari peran karyawan yang berkualitas dan produktif. Saat ini masih banyak perusahaan besar masih mengabaikan pentingnya kenyamanan dan kesehatan kerja karyawan, walaupun perusahaan tersebut juga telah menyediakan berbagai fasilitas dan sarana. Penyediaan jaminan keselamatan kerja dan kesehatan karyawan saja belum mencukupi pencapaian prinsip hidup sehat dalam bekerja karena karyawan masih memiliki resiko terganggu kesehatan atau terancam penyakit pada masa pensiun setelah mereka mengabdi.

Pada permasalahan ini peneliti mengamati mengenai jumlah kalori yang ideal menjadi asupan pada karyawan dalam melaksanakan tugasnya, terutama bagi karyawan dengan beban kerja otot maksimal dalam bekerja. Karyawan sering mengabaikan ketidakseimbangan antara kebutuhan konsumsi yang diterima dengan kebutuhan energi yang dikeluarkan pada saat bekerja. Hal ini dapat mengakibatkan terjadinya pengaruh penurunan produktivitas kerja karyawan dan bagi kesehatan ditandai dengan turunnya berat badan serta permasalahan rusaknya jaringan tubuh (Arisman, 2014). Energi yang dikeluarkan pada saat karyawan bekerja merupakan sesuatu yang sering dianggap remeh sehingga jarang diperhatikan perusahaan maupun karyawan itu sendiri. Padahal menggunakan energi dengan jumlah maksimal pada saat yang tidak sebentar dapat menimbulkan terjadinya kelelahan fisik (Auliana, 2001). Kelelahan menjadi lebih berbahaya bila terjadi pada mental manusia karena dapat berakibat pada berkurangnya konsentrasi dan terjadinya kesalahan kerja yang fatal (Nurmianto, 2004).

Tabel 1 menunjukkan bahwa karyawan buruh angkut mengalami permasalahan kekurangan kalori pada saat mereka melakukan aktivitas pekerjaan. Hal ini dapat dilihat dari selisih yang cukup signifikan antara jumlah kalori yang ada dan berapa kalori yang sebenarnya dibutuhkan oleh tubuh. 
Tabel 1. Data kebutuhan kalori pada buruh angkut dalam jam kerja (8 jam kerja)

\begin{tabular}{|c|c|c|c|c|c|c|c|c|}
\hline $\begin{array}{l}\text { Buruh } \\
\text { angkut }\end{array}$ & $\begin{array}{l}\text { Kalori } \\
\text { mengang } \\
\text { kut (kal/ } \\
\text { 1,5jam) }\end{array}$ & $\begin{array}{l}\text { Standard } \\
\text { aktivitas } \\
\text { berat } \\
\text { (kal/ } \\
\text { 1,5jam) }\end{array}$ & $\begin{array}{l}\text { Kalori di } \\
\text { luar } \\
\text { mengang } \\
\text { kut (kal/ } \\
\text { 5jam) }\end{array}$ & $\begin{array}{l}\text { Standard } \\
\text { aktivitas } \\
\text { sedang } \\
\text { (kal/ } \\
\text { 1,5jam) }\end{array}$ & $\begin{array}{l}\text { Kalori } \\
\text { istirahat } \\
\text { (kal/ } \\
\text { 1,5jam) }\end{array}$ & $\begin{array}{l}\text { Kalori } \\
\text { yang } \\
\text { dibutuh } \\
\text { kan } \\
\text { (kal/ } \\
\text { 8jam) }\end{array}$ & $\begin{array}{l}\text { Kalori } \\
\text { tersedia } \\
\text { (kal/ } \\
\text { 8jam) }\end{array}$ & $\begin{array}{l}\text { Jumlah } \\
\text { kekura } \\
\text { ngan } \\
\text { kalori } \\
\text { (kal/ } \\
\text { 8jam) }\end{array}$ \\
\hline Buruh 1 & 304,3519 & $300-375$ & 845,4219 & $625-1000$ & 101,4506 & 1251,22 & 1171,608 & 79,61638 \\
\hline Buruh 2 & 310,9425 & $300-375$ & 863,7292 & $625-1000$ & 103,6475 & 1278,32 & 1171,608 & 106,7112 \\
\hline Buruh 3 & 304,9913 & $300-375$ & 847,1979 & $625-1000$ & 101,6638 & 1253,85 & 1171,608 & 82,24492 \\
\hline Buruh 4 & 297,0863 & $300-375$ & 825,2396 & $625-1000$ & 99,02875 & 1221,36 & 1171,608 & 49,74658 \\
\hline Buruh 5 & 305,0194 & $300-375$ & 844,6719 & $625-1000$ & 101,6731 & 1253,97 & 1171,608 & 82,36054 \\
\hline Buruh 6 & 305,5875 & $300-375$ & 848,8542 & $625-1000$ & 101,8625 & 1256,3 & 1171,608 & 84,69617 \\
\hline Buruh 7 & 299,5294 & $300-375$ & & & 99,84313 & 1231,4 & 1171,608 & 59,79054 \\
\hline Buruh 8 & & & & & 100,9275 & 1244,78 & 1171,608 & 73,1645 \\
\hline Buruh 9 & & $300-375$ & & & & & 1171,608 & 106,8576 \\
\hline Buruh 10 & 308,0306 & $300-375$ & 855,6406 & $625-1000$ & 102,6769 & 1266,35 & 1171,608 & 94,74013 \\
\hline
\end{tabular}

Berdasarkan permasalahan umum perusahaan tersebut, peneliti merasa perlu melakukan analisis untuk mengukur kalori yang dibutuhkan dalam melaksanakan sebuah pekerjaan (Sediaoetama, 1989). Potensi yang dipergunakan saat mengukur kebutuhan kalori tubuh ini adalah dengan menganalisa detak jantung pada buruh angkut atau karyawan yang diteliti tersebut. Kemudian menentukan pilihan menu sehat sebelum dan sesudah buruh melakukan aktivitas kerja.

\section{METODE PENELITIAN}

Dalam pengumpulan informasi dan data-data pendukung yang diperlukan pada penelitian ini, maka peneliti melakukan serangkaian kegiatan antara lain (Moleong, 2007):

A. Riset Lapangan ( Field Research )

Merupakan metode penelitian yang dilakukan dengan jalan mengamati secara langsung suatu objek tertentu yang melakukan sejumlah kegiatan perusahaan yang sedang diteliti atau pengamatan langsung terhadap kegiatan di lapangan.

B. Riset Kepustakaan ( Library Research)

Metode penelitian berdasarkan sumber data yang diperoleh dari sejumlah buku, literature, majalah ilmiah, data informasi yang terdapat pada perpustakaan kampus, perpustakaan pemerintah kota dan perpustakaan Akademi Gizi ataupun yang pada instansi tempat penulis bekerja.

C. Identifikasi dan Perumusan Masalah

Dari data hasil survey dan wawancara, penulis menentukan permasalahan yang timbul berdasarkan hipotesa sebelum pengolahan data.

D. Menentukan Tujuan Penelitian

Berdasarkan perumusan masalah yang telah dibuat, dapat ditentukan beberapa tujuan penelitian. Tujuan penelitian ini bersifat sementara, ada kemungkinan tujuan penelitian ini tidak dapat dicapai atau timbul tujuan yang baru.

E. Pengumpulan Data

Mengumpulkan sejumlah data dengan cara melaksanakan pengamatan langsung dilapangan dan wawancara.

F. Pengolahan Data

Pengolahan data yang mesti dilakukan adalah dengan cara (Moleong, 2007):

1. Pengukuran detak jantung buruh angkut pada saat beraktivitas

2. Pengkonversian detak jantung kedalam kebutuhan kalori

3. Menentukan kandungan kalori pada makanan buruh angkut

4. Penyusunan menu usulan dengan kandungan kalori sesuai kebutuhan

G. Membuat Kesimpulan

Kesimpulan dibuat peneliti berdasarkan pengolahan dan analisis data. 
Gambar 1 menunjukkan diagram alir penelitian yang dilakukan.

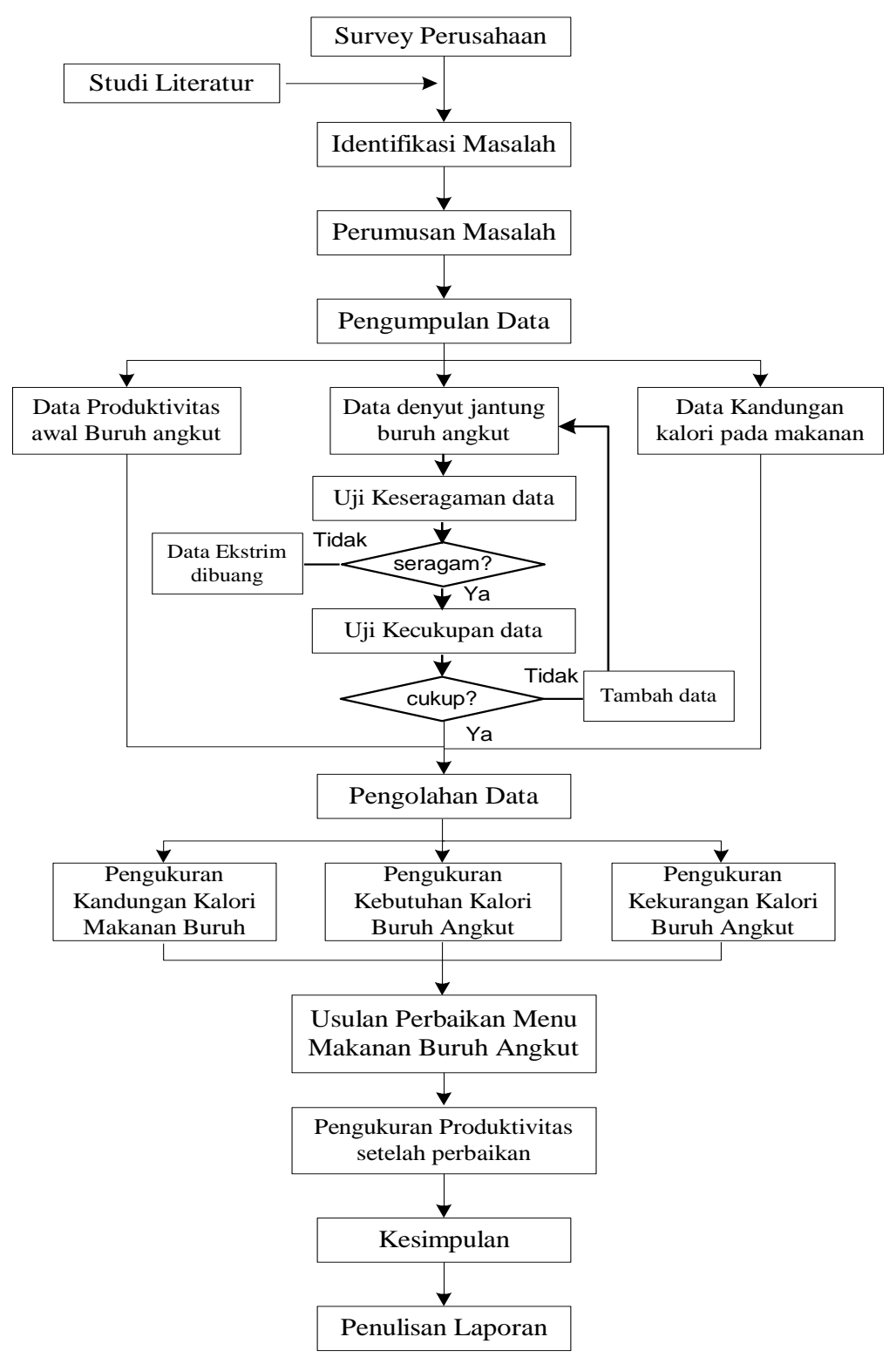

Gambar 1. Diagram alir penelitian

\section{HASIL DAN PEMBAHASAN}

Dalam penelitian ini pengumpulan data yang dilaksanakan demi adanya perlakuan pemenuhan asupan gizi bagi kebutuhan kalori pada buruh angkut gudang pabrik rokok. Pengumpulan data ini dilaksanakan dengan melalui pengamatan di lapangan (Field Research). Dimana peneliti mengadakan pengamatan terhadap obyek yang akan diteliti. Vitamind (2002) Adapun teknik yang digunakan yaitu:

1. Mengukur produktivitas buruh angkut dengan menggunakan analisa Bioritmik.

2. Mengukur beban faal kerja buruh angkut dengan pengukuran detak jantung.

3. Mengukur kebutuhan kalori buruh angkut.

4. Mengukur kandungan kalori makanan buruh.

Untuk pemenuhan kebutuhan kalori buruh angkut ini, diperlakukan data pendukung seperti terlihat pada Tabel 2 dan Tabel 3. 
Tabel 2. Data detak jantung normal buruh angkut sebelum bekerja

\begin{tabular}{cc}
\hline Buruh Angkut & Detak Jantung \\
\hline Buruh Angkut 1 & 75 \\
Buruh Angkut 2 & 72 \\
Buruh Angkut 3 & 76 \\
Buruh Angkut 4 & 69 \\
Buruh Angkut 5 & 74 \\
Buruh Angkut 6 & 70 \\
Buruh Angkut 7 & 71 \\
Buruh Angkut 8 & 73 \\
Buruh Angkut 9 & 75 \\
Buruh Angkut 10 & 72 \\
\hline
\end{tabular}

Tabel 3. Data detak jantung buruh angkut saat bekerja

\begin{tabular}{ccccc}
\hline Buruh angkut & $\begin{array}{c}\text { Mengangkut } \\
\text { tembakau }\end{array}$ & $\begin{array}{c}\text { Menjemur } \\
\text { tembakau }\end{array}$ & $\begin{array}{c}\text { Menyortir } \\
\text { tembakau }\end{array}$ & $\begin{array}{c}\text { Mengangkat } \\
\text { tembakau }\end{array}$ \\
\hline Buruh 1 & 126 & 108 & 104 & 114 \\
Buruh 2 & 126 & 109 & 106 & 112 \\
Buruh 3 & 131 & 111 & 107 & 114 \\
Buruh 4 & 129 & 112 & 108 & 116 \\
Buruh 5 & 126 & 108 & 105 & 111 \\
Buruh 6 & 131 & 113 & 109 & 117 \\
Buruh 7 & 129 & 112 & 108 & 116 \\
Buruh 8 & 130 & 110 & 106 & 113 \\
Buruh 9 & 128 & 109 & 107 & 114 \\
Buruh 10 & 128 & 110 & 108 & 115 \\
\hline Jumlah & 1284 & 1102 & 1068 & 1142 \\
\hline Rata-rata & 128,4 & 110,2 & 106,8 & 114,2 \\
\hline
\end{tabular}

\section{A. Pengukuran Detak Jantung}

Pengukuran detak jantung bertujuan untuk menentukan beban faal kerja buruh angkut (Nurmianto, 2004). Hal ini bertujuan untuk mengetahui apakah pekerjaan tersebut termasuk ringan, sedang ataupun berat. Alat yang digunakan dalam pengukuran detak jantung ini adalah Heart Rate Monitor. Pengukuran dilakukan pada dua kondisi, yaitu yang pertama pada saat buruh mengangkut tembakau dan yang kedua pada saat di luar mengangkut tembakau (buruh melakukan kegiatan selain mengangkut tembakau).

Sebelum dilakukan pengukuran nadi kerja dari para buruh angkut, terlebih dahulu dilakukan pengukuran detak jantung normal dari buruh angkut. Pengukuran dilakukan sebelum buruh angkut melakukan pekerjaan, yaitu sebelum jam kerja dimulai. Salah satu tujuan dari pengukuran detak jantung normal ini, untuk memastikan buruh dalam keadaan sehat dan tidak keadan tertekan.

\section{B. Pengamatan Menu Makan Buruh Angkut}

Pengamatan untuk penentuan kalori ini hanya dilakukan dalam satu minggu atau enam hari saja karena diasumsikan bahwa variasi dari menu makanan buruh angkut sangatlah terbatas. Hal ini disebabkan makanan buruh disediakan dari perusahaan sehingga tidak ada perbedaan menu dari satu buruh dengan buruh yang lain. Sebagai catatan bahwa menu makanan saat ada kedatangan truk maupun tidak ada, hal itu diperlakukan sama. 
Tabel 4. Data kandungan makanan hari pertama

\begin{tabular}{|c|c|c|c|c|c|}
\hline Jenis Makanan & Ukuran Makanan & $\begin{array}{c}\text { Kalori } \\
\text { (kalori) } \\
\text { Makan }\end{array}$ & $\begin{array}{l}\text { Karbohidrat } \\
\text { (kalori) } \\
\text { g }\end{array}$ & $\begin{array}{l}\text { Lemak } \\
\text { (gram) }\end{array}$ & $\begin{array}{c}\text { Protein } \\
\text { (gram) }\end{array}$ \\
\hline Nasi & 350 gram & 623 & 142,1 & 0,35 & 7,35 \\
\hline \multicolumn{6}{|l|}{ Urap: } \\
\hline Kacang panjang & 10 gram & 4,4 & 0,78 & 0,03 & 0,27 \\
\hline Daun singkong & 10 gram & 7,3 & 1,3 & 0,01 & 0,68 \\
\hline Tauge & 5 gram & 1,15 & 0,205 & 0,01 & 0,145 \\
\hline Tahu & 20 gram & 16 & 0,32 & 0,92 & 1,56 \\
\hline Tempe & 25 gram & 40 & 4 & 1,5 & 3 \\
\hline Ikan asin & 25 gram & 48,2 & 0 & 0,375 & 10,5 \\
\hline Es teh & 1 gelas & 137 & 33,2 & 0,3 & 0,3 \\
\hline \multicolumn{6}{|c|}{ Makan Sore } \\
\hline 1 porsi bakso : & & & & & \\
\hline Bakso daging & 5 biji sedang & 48 & 0,1 & 3 & 5 \\
\hline Tahu & 2 ptg sedang (50gr) & 40 & 0,8 & 2,3 & 3,9 \\
\hline Mie basah & 50 gram & 43 & 7 & 1,65 & 0,3 \\
\hline Lontong & 2 buah kecil (50gr) & 88 & 20 & 0 & 2 \\
\hline Jumlah & & 1178,05 & 84,810 & 4,771 & 13,88 \\
\hline
\end{tabular}

\section{Pengamatan Kegiatan Buruh Angkut}

Pengamatan kegiatan buruh angkut ini bertujuan untuk mengetahui aktivitas yang dikerjakan oleh buruh angkut pada saat mereka bekerja. Pengamatan ini dilakukan pada 10 orang buruh angkut pada bagian gudang. Kegiatan buruh angkut ini dibedakan menjadi dua, yaitu yang pertama kegiatan jika truk tembakau datang dan kegiatan pada saat tidak ada yang datang.

Berdasarkan pengamatan tidak terdapat banyak perbedaan antara kegiatan saat truk datang dan saat truk tidak datang, Perbedaanya hanya jika tidak ada truk yang datang, maka para buruh tidak perlu memindahkan tembakau dari truk ke gudang dan tidak perlu menimbang tembakau yang baru datang tersebut. Penelitian ini lebih memfokuskan pada kegiatan buruh angkut saat truk datang karena aktivitas terberat dilakukan buruh angkut adalah sewaktu memindahkan tembakau dari truk menuju ke gudang.

Tabel 5. Kegiatan buruh angkut saat kedatangan truk

\begin{tabular}{cl}
\hline Waktu & \multicolumn{1}{c}{ Kegiatan } \\
\hline $07.00-09.00$ & Menjemur tembakau yang masih basah \\
$09.00-11.00$ & Memindahkan tembakau dari truk menuju gudang dan menimbangnya \\
$11.00-11.30$ & Membolak balik tembakau yng di jemur \\
$11.30-13.00$ & Istirahat siang dan sholat \\
$13.00-15.00$ & Mengangkat tembakau sambal menyortir tembakau yang tidak layak \\
& produksi dan kotoran tembakau \\
$15.00-15.30$ & Istirahat dan pulang \\
\hline
\end{tabular}

Kedatangan truk tembakau ini bersifat konstan yaitu 3 truk setiap dua hari sekali. Setiap truk mengangkut kurang lebih $2375 \mathrm{~kg}$ tembakau (sekitar 72 keranjang). Jadi dalam satu hari diperkirakan seorang buruh angkut mengangkut sekitar 21-22 kali/keranjang.

\section{Perhitungan Detak Jantung}

Dari data detak jantung yang diperoleh, dilakukan perhitungan guna mengetahui kecukupan dan keseragaman data. Perhitungan yang dilakukan terlihat pada persamaan (1), (2), (3) dan (4). 


$$
s=\sqrt{\frac{\sum_{i=1}^{N}(X i-\bar{X})^{2}}{N-1}}=1,95536
$$

Dengan : Tingkat kepercayaan 95\% ( $\mathrm{k}=2)$

Tingkat ketelitian $10 \%$

$$
\begin{aligned}
& \mathrm{BKA}=\mathrm{X}+\mathrm{k} \cdot \mathrm{s}=128,4+(2)(1,955)=132 \\
& \mathrm{BKB}=\mathrm{X}-\mathrm{k} \cdot \mathrm{s}=128,4-(2)(1,955)=124 \\
& \mathrm{~N}^{\prime}=\left[\frac{k / s \sqrt{N\left(\sum X i^{2}\right)-\left(\sum X i\right)^{2}}}{\sum X i}\right]^{2}=0.082
\end{aligned}
$$

Berdasarkan nilai N' yang lebih kecil dibandingkan N, maka dapat diambil kesimpulan bahwa data sudah mencukupi. Setelah data dianggap seragam dan cukup dalam pengamatan untuk 6 hari kerja, maka disimpulkan bahwa aktivitas mengangkut tembakau merupakan beban faal kerja kategori berat. Hal ini dapat dilihat dari jumlah detak jantung rata-rata mengangkut tembakau sebesar $128 \mathrm{detak} / \mathrm{menit}$, nilai tersebut termasuk dalam golongan kerja berat. Sedangkan untuk aktivitas di luar mengangkut tembakau (menjemur, menyortir dan mengangkat) termasuk beban faal kerja kategori agak berat atau sedang. Hal ini dapat dilihat dari detak jantung rata-rata menjemur tembakau sebesar 110 detak/menit, menyortir tembakau sebesar $107 \mathrm{detak} / \mathrm{menit}$ dan mengangkat tembakau sebesar $114 \mathrm{detak} / \mathrm{menit}$. Semua nilai tersebut termasuk dalam golongan kerja agak berat atau sedang. Untuk penentuan jenis faal kerja, detak jantung buruh dibandingkan dengan tabel konversi faal kerja berikut pada Tabel 6.

Tabel 6. Nadi kerja menurut tingkat beban kerja

\begin{tabular}{lc}
\hline \multicolumn{1}{c}{ Beban Kerja } & Nadi Kerja (per menit) \\
\hline Sangat ringan & $<75-100$ \\
Ringan & $100-125$ \\
Agak berat & $125-150$ \\
Sangat berat & $150-175$ \\
Luar biasa berat & $>175$ \\
\hline
\end{tabular}

Berdasarkan tabel konversi maka disimpulkan bahwa dalam pekerjaan buruh angkut selama 1,5 jam merupakan kategori kerja berat dan selama 5 jam merupakan kategori kerja sedang atau agak berat.

\section{E. Kandungan Kalori Makanan Buruh Sebelum Perbaikan}

Perhitungan kandungan kalori bertujuan untuk mengetahui ketersediaan jumlah kalori yang dimiliki buruh angkut sebelum dilakukan perbaikan menu. Untuk mengetahui kandungan kalori tersebut, digunakan tabel konversi kandungan kalori pada makanan dari berbagai sumber literatur buku gizi. Dari data kandungan kalori makanan yang diketahui, dapat ditentukan ratarata jumlah kalori yang dimiliki buruh angkut seperti ditunjukkan pada Tabel 7. 
Tabel 7. Rata-rata jumlah kandungan makanan yang dimiliki buruh angkut

\begin{tabular}{lcccc}
\hline $\begin{array}{c}\text { Hari } \\
\text { pengamatan }\end{array}$ & $\begin{array}{c}\text { Jumlah kalori dalam } \\
\text { makanan }(\text { kal) }\end{array}$ & $\begin{array}{c}\text { Karbohidrat } \\
(\mathbf{\%})\end{array}$ & $\begin{array}{c}\text { Lemak } \\
(\boldsymbol{\%})\end{array}$ & $\begin{array}{c}\text { Protein } \\
(\boldsymbol{\%})\end{array}$ \\
\hline Hari ke-1 & 1178,05 & 84,810 & 4,771 & 13,881 \\
Hari ke-2 & 1156,8 & 88,580 & 6,233 & 7,057 \\
Hari ke-3 & 1211,95 & 81,489 & 6,611 & 11,899 \\
Hari ke-4 & 1164,7 & 86,747 & 5,963 & 7,289 \\
Hari ke-5 & 1143,05 & 85,475 & 4,909 & 9,616 \\
Hari ke-6 & 1169,1 & 86,629 & 6,213 & 7,156 \\
\hline Jumlah & $\mathbf{7 . 0 2 3 , 6 5}$ & $\mathbf{5 1 3 , 7 3 0}$ & $\mathbf{3 4 , 7 0 0}$ & $\mathbf{5 6 , 8 9 8}$ \\
\hline Rata-rata & $\mathbf{1 1 7 1 , 6 0 8}$ & $\mathbf{8 5 , 6 2 2}$ & $\mathbf{5 , 7 8 3}$ & $\mathbf{9 , 4 8 3}$ \\
\hline
\end{tabular}

Berdasarkan pengujian kecukupan data kandungan kalori makanan buruh angkut, didapatkan $\mathrm{N}^{\prime}=0,134$. Dilihat dari nilai $\mathrm{N}^{\prime}$ yang lebih kecil dibandingkan $\mathrm{N}$, maka dapat diambil kesimpulan bahwa data sudah mencukupi. Hal ini menunjukkan keenam data kandungan kalori makanan ini sudah cukup mewakili.

\section{F. Penentuan Kebutuhan Kalori Buruh}

Penentuan kebutuhan kalori buruh angkut mengunakan rumus kebutuhan kalori berdasarkan koefisien tingkat pekerjaan, dituliskan sebagai berikut (Suma'mur, 1987):

Kegiatan Ringan $=1,6 \times$ Metabolisme Basal

Kegiatan Sedang $=2,5 \times$ Metabolisme Basal

Kegiatan Berat $=3,0 \times$ Metabolisme Basal

Dengan mengacu pada data detak jantung kesepuluh buruh angkut, dapat diketahui bahwa buruh angkut melakukan kerja berat selama 1,5 jam, kerja sedang selama 5 jam, dan waktu istirahat selama 1 jam. Rumus yang digunakan hanya untuk kategori pekerjaan sedang dan berat saja, dengan menghitung besarnya Metabolisme Basal (MB) dari setiap buruh angkut. Perhitungan Metabolisme Basal untuk laki-laki ditunjukkan pada persamaan (5).

$$
\text { M B laki-laki }=66,42+(13,75 \times \mathrm{BB})+(5 \times \mathrm{TB})-(6,78 \times \mathrm{U})
$$

Dengan : BB merupakan berat tubuh pada satuan kilogram,

TB merupakan tinggi badan pada centimeter,

$\mathrm{U}$ adalah usia dalam satuan tahun.

Tabel 8. Perhitungan metabolisme basal buruh angkut

\begin{tabular}{ccccc}
\hline Buruh & $\begin{array}{c}\text { Berat Badan } \\
(\mathbf{k g})\end{array}$ & $\begin{array}{c}\text { Tinggi Badan } \\
(\mathbf{c m})\end{array}$ & Usia (tahun) & $\begin{array}{c}\text { Metabolisme } \\
\text { Basal (kal/hari) }\end{array}$ \\
\hline Buruh 1 & 69 & 165 & 32 & 1623,21 \\
Buruh 2 & 68 & 168 & 27 & 1658,36 \\
Buruh 3 & 70 & 167 & 35 & 1626,62 \\
Buruh 4 & 68 & 160 & 32 & 1584,46 \\
Buruh 5 & 69 & 162 & 30 & 1621,77 \\
Buruh 6 & 68 & 165 & 29 & 1629,8 \\
Buruh 7 & 67 & 164 & 31 & 1597,49 \\
Buruh 8 & 70 & 166 & 36 & 1614,84 \\
Buruh 9 & 69 & 168 & 29 & 1658,55 \\
Buruh 10 & 67 & 169 & 28 & 1642,83 \\
\hline
\end{tabular}

Setelah diketahui besarnya Metabolisme Basal bagi setiap buruh, kemudian dihitung kebutuhan kalori pada jam kerja (8 jam kerja). Perhitungan dilakukan melalui memasukkan jumlah Metabolisme Basal tersebut dalam rumus kalori kerja dengan menggunakan rumus kerja sedang dan kerja berat. 


\section{G. Kalori yang Dimiliki Buruh Angkut}

Dengan data jumlah kalori yang dimiliki buruh angkut, dapat ditentukan kekurangan kalori buruh angkut yang seharusnya terpenuhi dari makanan yang disediakan oleh pihak perusahaan.

Tabel 9. Perhitungan kalori pada jam kerja (8 jam)

\begin{tabular}{|c|c|c|c|c|c|}
\hline Buruh & $\begin{array}{l}\text { Metabolism } \\
\text { e Basal }\end{array}$ & $\begin{array}{c}\text { Aktivitas } \\
\text { Berat 1,5jam } \\
\text { (kal) } \\
{[1,5 / 24(3,0 x} \\
\text { MB)] }\end{array}$ & $\begin{array}{c}\text { Aktivitas } \\
\text { Sedang 5jam } \\
\text { (kal) } \\
{[5 / 24(2,0 x} \\
\text { MB)] }\end{array}$ & $\begin{array}{c}\text { Istirahat } \\
\text { 1,5jam (kal) } \\
{[1,5 / 24(2,0 x} \\
\text { MB)] }\end{array}$ & $\begin{array}{c}\text { Total } \\
\text { Kebutuhan } \\
\text { Kalori }\end{array}$ \\
\hline Buruh 1 & 1623,21 & 3043,519 & 8454,219 & 1014,506 & 1251,224 \\
\hline Buruh 2 & 1658,36 & 3109,425 & 8637,292 & 1036,475 & 1278,319 \\
\hline Buruh 3 & 1626,62 & 3049,913 & 8471,979 & 1016,038 & 1253,853 \\
\hline Buruh 4 & 1584,46 & 2970,863 & 8252,396 & 9902,875 & 1221,355 \\
\hline Buruh 5 & 1621,77 & 3050,194 & 8446,719 & 1016,731 & 1253,969 \\
\hline Buruh 6 & 1629,8 & 3055,875 & 8488,542 & 1018,625 & 1256,304 \\
\hline Buruh 7 & 1597,49 & 2995,294 & 832,026 & 9984,313 & 1231,399 \\
\hline Buruh 8 & 1614,84 & 3027,825 & 8410,625 & 1009,275 & 1244,773 \\
\hline Buruh 9 & 1658,55 & 3109,781 & 8638,281 & 1036,594 & 1278,466 \\
\hline Buruh 10 & 1642,83 & 3080,306 & 8556,406 & 1026,769 & 1266,348 \\
\hline \multicolumn{5}{|c|}{ Jumlah kebutuhan rata-rata } & 1253,601 \\
\hline
\end{tabular}

Kekurangan jumlah kalori ini hanya terjadi pada hari kedatangan truk saja. Berdasarkan fakta inilah maka diperlukan suatu perbaikan menu makanan dari buruh angkut tersebut.

\section{H. Produktivitas}

Data produktivitas awal ini diperlukan sebagai pembanding dengan produktivitas setelah perbaikan menu makanan. Pada pengukuran produktivitas buruh angkut ini peneliti mengganalisa penggunaan waktu kerja, mengingat kegiatan dari buruh angkut ini tidak memiliki waktu sandart yang pasti. Penentuan produktivitas waktu yang digunakan buruh angkut, peneliti menggunakan grafik bioritmik sebagai alat bantu untuk mengetahui penggunaan waktu kerja oleh para buruh angkut. Sebelummya peneliti mengkategorikan kegiatan-kegiatan buruh angkut kedalam kegiatan produktif dan non produktif. Yang termasuk dalam kegiatan produktif antara lain :

1. Menyiapkan tembakau yang akan dijemur

2. Menyiapkan area penjemuran

3. Menjemur tembakau

4. Meratakan tembakau yang dijemur

5. Menyortir tembakau

6. Menurunkan tembakau dari truk

7. Menimbang tembakau yang baru dating

8. Membawa tembakau ke gudang

9. Membolak-balik tembakau yang dijemur

10. Menyiapkan tempat tembakau kering

11. Memasukkan tembakau kering pada tempatnya

12. Memasukkan tembakau kering ke gudang

Sedangkan kegiatan yang termasuk dalam kegiatan non produktif antara lain :

1. Mengenakan atribut-atribut kerja (Topi, masker, sarung tangan)

2. Ngobrol dengan teman

3. Menunggu kedatangan truk

4. Menunggu pergantian truk

5. Duduk-duduk sambil kipas-kipas

6. Mengambil minum

7. Berdiri sambil istirahat 


\section{Pemenuhan Kebutuhan Kalori Perbaikan Menu Makanan}

Perbaikan menu makanan merupakan hal yang penting. Hal ini disebabkan dengan semakin berkembangnya pasar global, maka akan ditetapkan standart-standart kesehatan kerja yang akan menjadi salah satu patokan diakuinya suatu perusahaan. Dari perhitungan yang telah dilakukan, terlihat bahwa masih banyak jumlah kekurangan kalori yang dialami oleh buruh angkut. Jika dilihat dari menu makanan harian buruh angkut, menu makanan mereka belum memenuhi kriteria empat sehat lima sempurna karena tidak adanya menu buah dan susu sebagai pelengkap. Kalsium susu dibutuhkan untuk menjaga tulang kita agar tetap kuat. Selain itu susu merupakan salah satu sumber kalori dengan kandungan karbohidrat, lemak dan proteinnya tidak terlalu tinggi namun kandungan kalsium yang cukup tinggi (Sediaoetama, 1989). Konsumsi susu juga perlu menjadi perhatian (terutama susu sapi), yaitu bahwa susu memiliki struktur yang rumit. Susu sapi memiliki kadar kasein (salah satu bentuk protein yang kasar dan kental) 300\% lebih tinggi dibandingkan dengan ASI, sehingga terlalu berat bagi sistem pencernaan manusia. Susu sapi sebaiknya tidak dikonsumsi dengan makanan lain, terutama makanan yang proses pencernaanya juga rumit seperti daging karena susu yang tidak bisa dicerna dengan baik akan meninggalkan residu yang menimbulkan efek toksin dan dapat menyebabkan alergi atau diare. Untuk menghindari hal tersebut, maka perlu menyertakan menu susu sapi pada pagi hari sebelum buruh mulai bekerja. Sedangkan buah-buahan merupakan makanan pembentuk basa dalam tubuh. Agar tubuh tetap sehat dan dapat berfungsi secara optimal perlu untuk menyeimbangkan antara asam basa pada jaringan tubuh dan darah yang mesti pada posisi $\mathrm{pH}$ 7,3-7,5 (Arisman, 2014).

Namun jika dilihat pada menu keseharian konsumsi masyarakat saat ini biasanya secara dominan merupakan asupan pembentuk asam dan tidak banyak yang merupakan asupan pembentuk basa. Hal ini menandakan komposisi karbohidrat dan lauk yang dari protein semisal ikan/telur, daging biasanya lebih banyak dibandingkan sayuran segar dan buah. Kelebihan berat badan, nyeri lambung, sariawan, atau flu merupakan gejala dengan tingkat keasaman yang telah tinggi. Posisi ini dapat menjadi lebih buruk bila diperparah dengan membiasakan makan melalui asupan yang rendah energi dan kurang bergizi (Auliana, 2001). Sangat disayangkan apabila kebutuhan akan susu dan buah-buahan ini tidak terpenuhi. Agar organ-organ dalam tubuh dapat berfungsi dengan baik, tubuh juga membutuhkan karbohidrat sebanyak mungkin (maksimal) 60$70 \%$, protein $10-15 \%$ dan lemak $20-30 \%$ dari kebutuhan energi total.Untuk itu perlu dilakukan perbaikan menu makanan, khusunya untuk buruh angkut.

Pada perhitungan kandungan makanan buruh terlihat bahwa masih terlalu banyaknya kandungan karbohidrat, yaitu sekitar 85,6 \% maka perlu dilakukan pengurangan kandungan karbohidrat pada makanan buruh angkut dengan mengurangi takaran sumber karbohidrat terbesar, yaitu dari nasi. Untuk penambahan menu makanan digunakan kekurangan kalori terbesar sebagai patokan, yaitu dengan mengurangi takaran nasi \pm 50 gram yang memiliki nilai kalori sebesar 89 kalori sehingga rata-rata kekurangan menjadi (106,85 kal + 89 kal) 195,85 kalori setiap harinya. Jadi penambahan menu yang dilakukan setidaknya mengandung rata-rata 195,85 kalori

\section{SIMPULAN}

Pekerjaan yang dilakukan oleh buruh angkut adalah 1,5 jam termasuk pekerjaan berat, 5 jam pekerjaan sedang dan 1,5 jam istirahat dengan kebutuhan kalori rata-rata $1253.601 \mathrm{kal} / 8 \mathrm{jam}$ kerja. Tubuh akan mengalami kekurangan kalori pada saat mereka bekerja kurang lebih sekitar $6,5 \%(106,8576 \mathrm{kal} / 8 \mathrm{jam})$ dari makanan yang telah mereka makan setiap harinya. Setelah dilakukan perhitungan kandungan makanan terhadap kalori sesudah dilakukan perbaikan didapatkan rata-rata sebesar 1284,013 kal/8jam, mengalami peningkatan sebesar 9,63\% dari kandungan kalori makanan rata-rata sebelum improvement. Produktivitas kerja sebelum perbaikan yaitu sebesar 73,99\% meningkat sebesar $0,81 \%$ menjadi $74,81 \%$ setelah perbaikan. 


\section{DAFTAR PUSTAKA}

Arisman. (2014). Gizi dalam Daur Kehidupan. Jakarta : Penerbit Buku Kedokteran EGC. Auliana. (2001). Rizqi, Gizi \& Pengolahan Pangan. Yogyakarta : AdiCita Karya Nusa. Grandjean, E. (1982). Fitting the Task to the Man. London : Taylor \& Fancis Ltd.

Moleong, L. J. (2007). Metodologi Penelitian Kualitatif Edisi Revisi Bandung. Bandung : PT Remaja Rosdakarya.

Nurmianto, E. (2004). Ergonomi Konsep Dasar dan Aplikasinya. Surabaya : ITS.

Sediaoetama, A. D. (1989). Ilmu Gizi untuk Mahasiswa dan Profesi. Jakarta : Dian Rakyat. Suma'mur. (1987). Ergonomi untuk Produktivitas Kerja. Dharma Bhakti Muara Agung.

Vitamind. (2002). Temukan Golden Moment Anda Panduan Praktis Bioritme. Jakarta : Gramedia Pustaka Utama.

Wignjosoebroto, S. (1992). Ergonomi Studi Gerak dan Waktu. Jakarta : Guna Widya. 